\title{
Variations in MHC class I antigen presentation and
}

\section{immunopeptidome selection pathways [version 1; peer}

\section{review: 3 approved]}

\author{
Anita J. Zaitouna (D), Amanpreet Kaur, Malini Raghavan (iD) \\ Department of Microbiology and Immunology, Michigan Medicine, University of Michigan, Ann Arbor, MI, USA
}

V1 First published: 28 Sep 2020, 9(Faculty Rev):1177

https://doi.org/10.12688/f1000research.26935.1

Latest published: 28 Sep 2020, 9(Faculty Rev):1177

https://doi.org/10.12688/f1000research.26935.1

\section{Abstract}

Major histocompatibility class I (MHC-I) proteins mediate immunosurveillance against pathogens and cancers by presenting antigenic or mutated peptides to antigen receptors of CD8+ T cells and by engaging receptors of natural killer (NK) cells. In humans, MHC-I molecules are highly polymorphic. MHC-I variations permit the display of thousands of distinct peptides at the cell surface. Recent mass spectrometric studies have revealed unique and shared characteristics of the peptidomes of individual MHC-I variants. The cell surface expression of MHC-I-peptide complexes requires the functions of many intracellular assembly factors, including the transporter associated with antigen presentation (TAP), tapasin, calreticulin, ERp57, TAP-binding protein related (TAPBPR), endoplasmic reticulum aminopeptidases (ERAPs), and the proteasomes. Recent studies provide important insights into the structural features of these factors that govern MHC-I assembly as well as the mechanisms underlying peptide exchange. Conformational sensing of MHC-I molecules mediates the quality control of intracellular MHC-I assembly and contributes to immune recognition by CD8 at the cell surface. Recent studies also show that several MHC-I variants can follow unconventional assembly routes to the cell surface, conferring selective immune advantages that can be exploited for immunotherapy.

\section{Keywords}

MHC class I, HLA class I

\section{Open Peer Review}

Approval Status

1

2

3

version 1

28 Sep 2020

Faculty Reviews are review articles written by the prestigious Members of Faculty Opinions. The articles are commissioned and peer reviewed before publication to ensure that the final, published version is comprehensive and accessible. The reviewers who approved the final version are listed with their names and affiliations.

1. David Margulies, NIAID, National Institutes of Health, Bethesda, USA

\section{Nikolaos G Sgourakis, University of} California Santa Cruz, Santa Cruz, USA Andrew C. McShan, University of California Santa Cruz, Santa Cruz, USA

3. Christian Münz, University of Zürich, Zürich, Switzerland

Any comments on the article can be found at the end of the article. 
Corresponding author: Malini Raghavan (malinir@umich.edu)

Author roles: Zaitouna AJ: Conceptualization, Writing - Original Draft Preparation, Writing - Review \& Editing; Kaur A: Writing - Original Draft Preparation, Writing - Review \& Editing; Raghavan M: Conceptualization, Funding Acquisition, Project Administration, Supervision, Writing - Review \& Editing

Competing interests: No competing interests were disclosed.

Grant information: This work was supported by the National Institute of Allergy and Infectious Diseases of the National Institutes of Health (grants RO1AI123957, R01AI044115, and R21AI126054 to MR and grants T32AI007413 and T32AI007528 to AJZ) and by the University of Michigan Fast Forward Protein Folding Disease Initiative.

The funders had no role in study design, data collection and analysis, decision to publish, or preparation of the manuscript.

Copyright: @ 2020 Zaitouna AJ et al. This is an open access article distributed under the terms of the Creative Commons Attribution License, which permits unrestricted use, distribution, and reproduction in any medium, provided the original work is properly cited.

How to cite this article: Zaitouna AJ, Kaur A and Raghavan M. Variations in MHC class I antigen presentation and immunopeptidome selection pathways [version 1; peer review: 3 approved] F1000Research 2020, 9(Faculty Rev):1177

https://doi.org/10.12688/f1000research.26935.1

First published: 28 Sep 2020, 9(Faculty Rev):1177 https://doi.org/10.12688/f1000research.26935.1 


\section{Introduction}

Major histocompatibility class I (MHC-I) proteins are expressed on the cell surface of nucleated cells and serve critical functions in the immune response by mediating the activation of $\mathrm{CD}^{+} \mathrm{T}$ cells and regulating the activity of natural killer (NK) cells. MHC-I molecules form trimeric complexes that consist of a heavy chain, a light chain (beta2-microglobulin, or $\beta 2 \mathrm{~m}$ ), and peptide. T-cell receptors of $\mathrm{CD}^{+} \mathrm{T}$ cells and the CD8 co-receptors of the same cell engage the membranedistal peptide-binding domain and the membrane-proximal domains, respectively, of individual peptide-MHC-I molecules, providing the initiating signal for $\mathrm{CD}^{+}$T-cell activation (reviewed in 1) (Figure 1A). Various NK cell receptors can bind to specific MHC-I molecules to inhibit or initiate NK cell activation (reviewed in 1). The CD8 co-receptor is also expressed on NK cells. Whereas the CD8 $\alpha \beta$ heterodimer is expressed on $\mathrm{CD}^{+} \mathrm{T}$ cells, a subset of $\mathrm{NK}$ cells expresses the CD8 $\alpha \alpha$ homodimer (Figure 1A). Recent studies show that KIR3DL1, an NK cell receptor for human MHC-I, uses the CD8 $\alpha \alpha$ homodimer as a co-receptor ${ }^{2}$. Thus, CD8 functions as an MHC-I engaging co-receptor, not just for $\mathrm{T}$ cells but also for NK cells.

Since MHC-I molecules are critical ligands for receptors of both $\mathrm{T}$ cells and NK cells, their assembly and expression are subject to elaborate cellular quality control. The MHC-I complex

\section{A) MHC-I Surface Interactions}

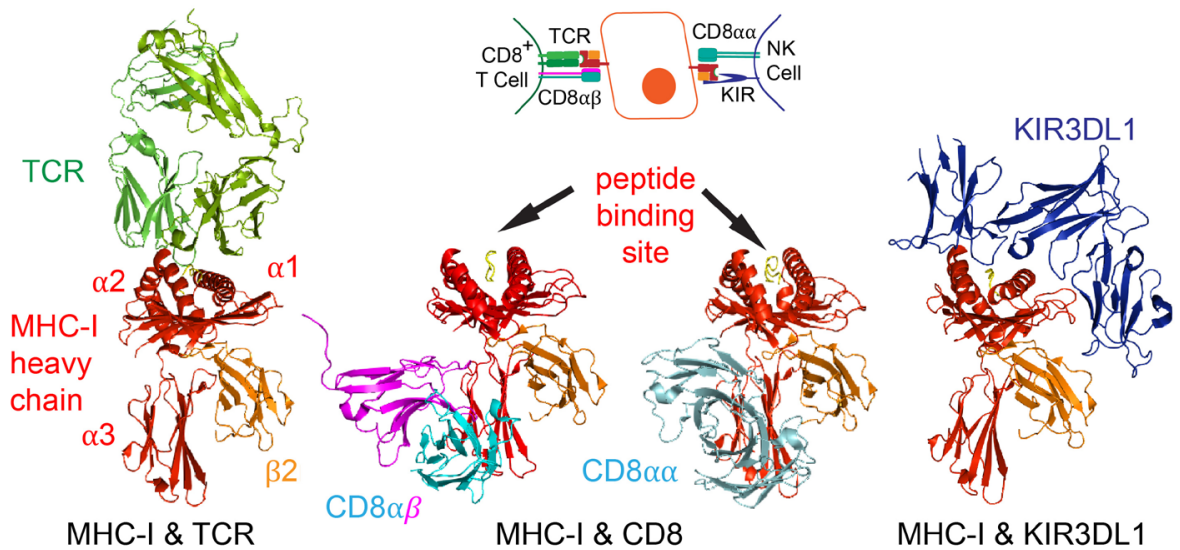

\section{B) MHC-I Assembly}
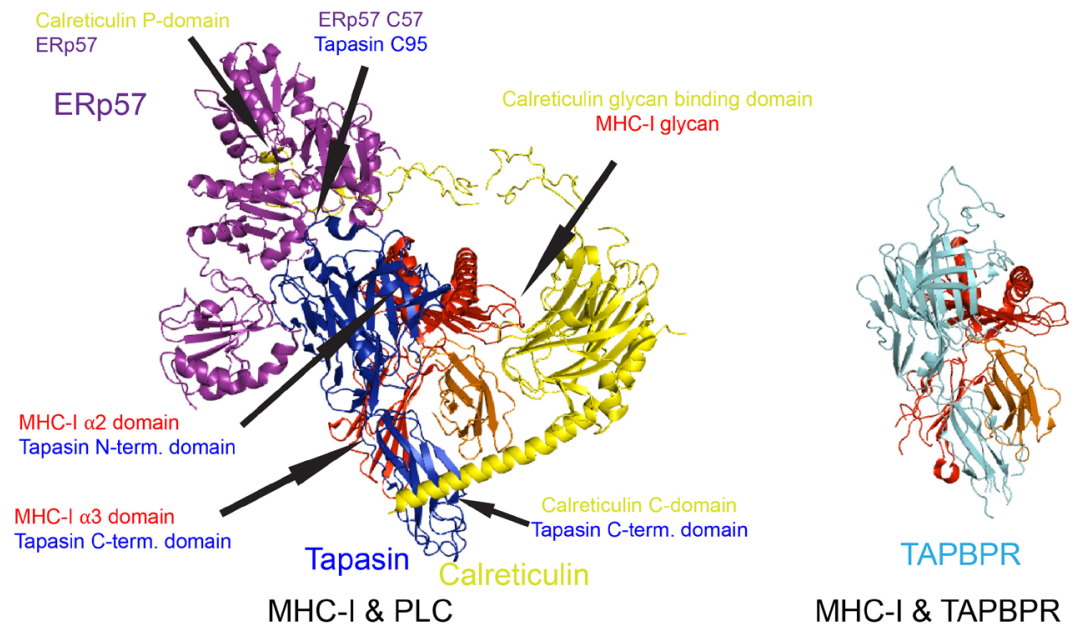

Figure 1. Major histocompatibility class I (MHC-I) surface interactions and assembly. (A) Crystal structure and cartoon representation of MHC-I (red: heavy chain, orange: $\beta 2 \mathrm{~m}$, yellow: peptide)/TCR (green) (PDB 5C073) on CD8 ${ }^{+} \mathrm{T}$ cells, MHC-I/CD8 co-receptor (cyan and magenta) (PDB 3DMM ${ }^{4}$ and PDB 3QZW ${ }^{5}$ ), or MHC-I/KIR3DL1 (blue) on natural killer (NK) cells (PDB 5B386). (B) Cryo-EM structure of MHC-I in the PLC (yellow: calreticulin, blue: tapasin, purple: ERp57) (PDB 6ENY7 adapted from data freely accessible at: https://www. rcsb.org/structure/6ENY) or with TAPBPR (cyan) (PDB 5WER ${ }^{8}$ ) in the peptide-deficient form. Arrows highlight interactions between tapasin and MHC-I, calreticulin and the MHC-I glycan, calreticulin and tapasin, calreticulin and ERp57, and tapasin and Erp57. $32 \mathrm{~m}$, beta2microglobulin; KIR, killer cell immunoglobulin-like receptor; PLC, peptide loading complex; TAPBPR, transporter associated with antigen presentation-binding protein related; TCR, T-cell receptor. 
is assembled in the endoplasmic reticulum (ER), travels to the Golgi apparatus, and follows the secretory pathway to reach the cell surface ${ }^{9,10}$. Assembly in the ER occurs with the help of the peptide loading complex (PLC), a large macromolecular assembly comprising TAP subunits TAP1 and TAP2, tapasin, ERp57, and calreticulin in addition to MHC-I heavy chain and $\beta 2 \mathrm{~m}^{9}$. Apart from the PLC proteins, ERAP variants ERAP1 and ERAP2 and TAPBPR are important players in peptide trimming and peptide quality control, respectively.

In humans, three sets of classical and non-classical MHC-I genes as well as several non-classic MHC-I genes encode the heavy chains of MHC-I proteins. The classical MHC-I genes are the human leukocyte antigen class I (HLA-I) genes HLA-A, $H L A-B$, and $H L A-C$. Each gene is polymorphic with multiple allelic variations, and more than 19,000 alleles were listed for classical HLA-I genes on the IPD-IMGT/HLA Database as of May $2020^{11}$. Allelic variants of individual genes frequently occur as groups of co-inherited alleles called haplotypes ${ }^{12}$, which are jointly implicated in various disease susceptibilities ${ }^{13}$. The non-classical MHC-I genes encode HLA-E, HLA-F, HLA-G, cluster of differentiation 1 (CD1), and MHC-related protein 1 (MR1). These genes display low allelic polymorphisms and engage various immune receptors to activate or inhibit immunity ${ }^{14}$. A number of recent studies have addressed the question of how classical MHC-I polymorphisms influence the assembly, conformation, and expression of individual human MHC-I variants, the impact of polymorphisms on the peptide repertoires, and the functional consequences for immunity, topics that are the focus of this review article.

\section{Peptidomes of HLA-I molecules and the prevalence of spliced and post-translationally modified peptides} The heavy chains of MHC-I molecules contain a peptide-binding site (Figure 1), which is also the site of amino acid variations that define MHC-I polymorphisms, resulting in variable peptidebinding specificities (Figure 2) ${ }^{15}$. Immunoaffinity purification in conjunction with mass spectrometric (MS) studies using data-independent acquisition (DIA) MS approaches has allowed for the identification of thousands of peptides associated with individual HLA-I variants (designated the peptidome) ${ }^{16}$. Many of the MS studies have used HLA-I null cells that are engineered to express single HLA-I molecules (termed monoallelic), which are affinity-purified, followed by peptide elution and sequencing by liquid chromatography tandem MS (LC-MS/MS) approaches ${ }^{17-19}$. The monoallelic approach is advantageous over other methods in that the isolated peptidome can be attributed to a specific HLA-I without the need for prediction algorithms to assign peptides to a given HLA-I. A pan HLA-I antibody $(\mathrm{W} 6 / 32)^{20}$ can be used for immunoisolating most HLA-I proteins. On the other hand, prediction algorithms are typically required for peptide/HLA assignments when primary cells are used, which typically express six HLA-I molecules, two each of HLA-A, HLA-B, and HLA-C. Alternatively, immunoaffinity purification can be modified to target specific MHC-I molecules within primary tissues and cells via the use of antibodies specific to a small subset of MHC-I. Owing to the large diversity and close relatedness of many MHC-I molecules, few such HLA-I allotype-specific antibodies exist, and careful specificity controls must be performed prior to their use. The rather long duration of the affinity purification process is expected to result in the capture of only a subset of peptides displayed on the cell surface, especially those with high affinity and abundance ${ }^{21,22}$. Additionally, other parameters, including chemical properties of individual peptides, which have to be able to bind a C18 column and be ionizable for successful MS-based detection, can skew peptide detection ${ }^{23}$. Nonetheless, the approach has resulted in the generation of datasets containing the identities of large numbers of actual HLA-Ibound peptides, expanded the list of alleles for which peptidome datasets are available, helped improve predictive algorithms for peptide binding to HLA-I, and confirmed that a single HLA-I displays thousands of cell surface peptides ${ }^{17,19}$. A recent study exploited the monoallelic approach to define the peptidomes of 95 HLA-I proteins ${ }^{19}$. The resulting datasets have confirmed that peptide-binding motifs and sub-motifs are shared across HLA-I molecules that bear similarities in their peptide-binding sites (Figure 2, individual supertypes) and that 9-mer peptides are dominant among the majority of tested allotypes (except for HLA-B*18:01 and HLA-B*52:01). The peptidome data have been combined with transcript abundance and peptide processing data to improve the available tools used for the prediction of peptides binding to a given HLA- ${ }^{19}$.

The proteasomes are the major cellular proteolytic system to generate peptides from precursor protein for MHC-I binding ${ }^{24}$. In addition to conventional proteolytic activities, proteasomes are known to be able to catalyze transpeptidation reactions to generate spliced epitopes comprising non-contiguous segments from precursor proteins ${ }^{25,26}$. Recent studies have attempted to quantify the fraction of HLA-I ligandomes that correspond to spliced epitopes, both cis-spliced (spliced peptides originating from the same precursor) and trans-spliced (spliced peptides originating from different precursors) $)^{18,27,28}$. The validity of some of the approaches used for quantifying the spliced peptide fraction remains somewhat controversial ${ }^{28}$; to date, only a small number of the possible spliced peptides have been confirmed as products of proteasomal splicing or directly validated as spliced epitopes using other approaches. Thus, although it is clear that spliced peptides exist and function as T-cell epitopes in the immune response ${ }^{25,26}$, further studies are required to understand how frequently spliced epitopes might contribute to T-cell responses. Besides splicing, post-translational modifications of MHC-I epitopes further expand the peptide repertoires of presenting cells ${ }^{29}$. Specific forms of glycopeptides have also been identified in leukemia patients that can activate cytotoxic T-cell responses ${ }^{30}$.

\section{The classical MHC-I assembly pathway and its dysfunction in disease}

In the MHC-I assembly pathway, peptides are generated in the cytosol by the proteasome. A fraction of the peptides are brought into the ER via TAP in an ATP-driven process ${ }^{31}$. The PLC brings into close proximity many components for both stabilizing nascent MHC-I molecules and facilitating peptide binding to MHC-I heterodimers ${ }^{9}$. A cryogenic electron 

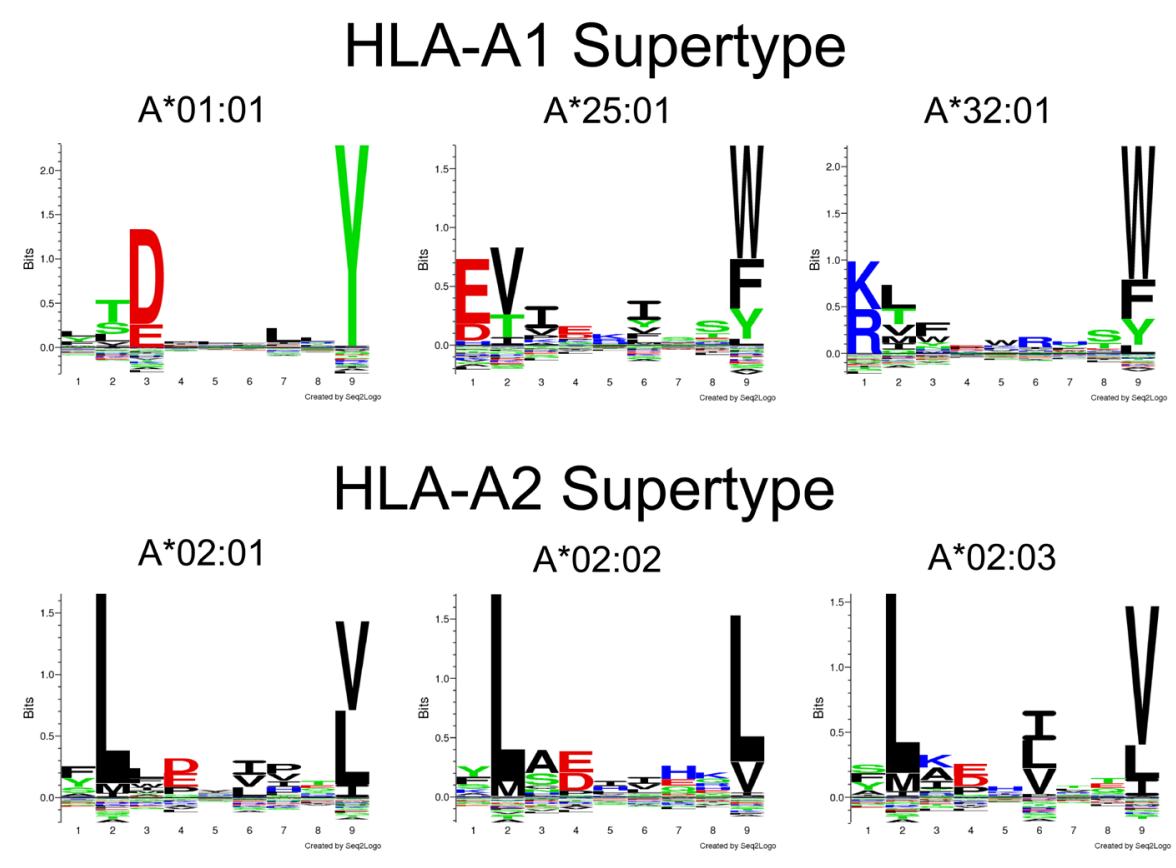

HLA-A3 Supertype
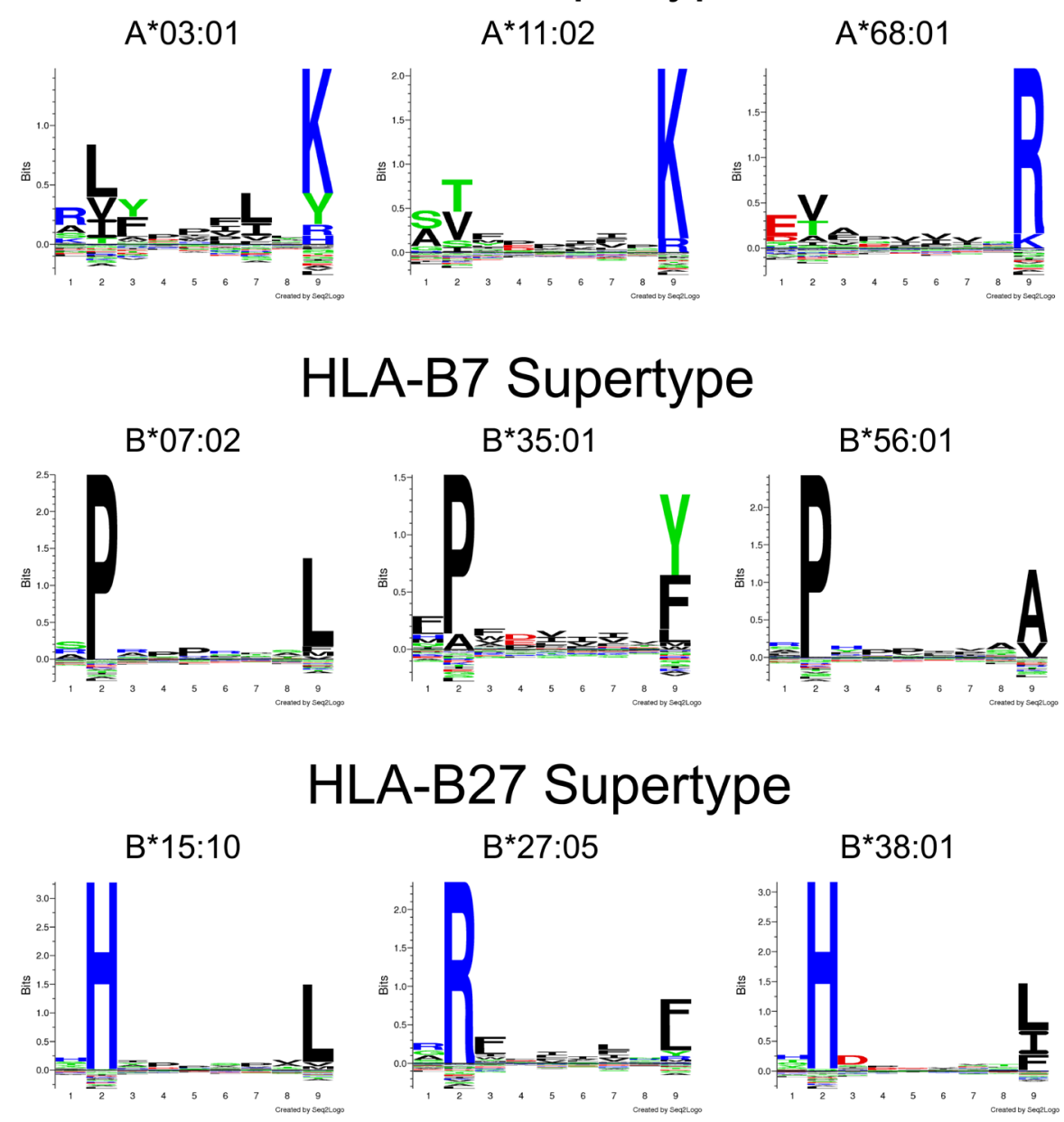


\section{HLA-B44 Supertype}

$B^{*} 40: 01$

B*44:02

$B^{*} 45: 01$
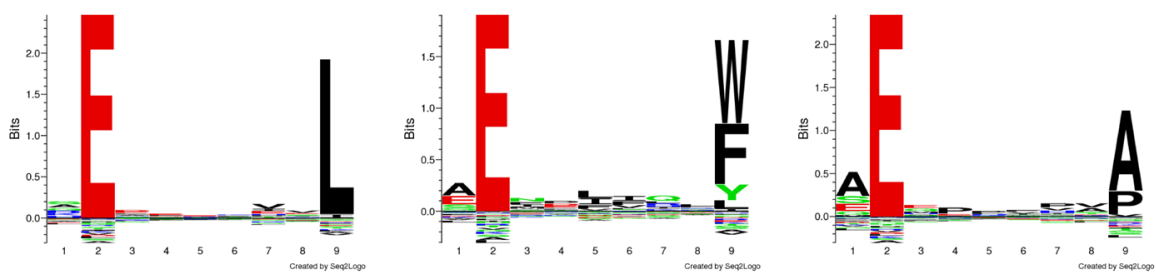

\section{HLA-B62 Supertype}

$B * 15: 01$

B*46:01

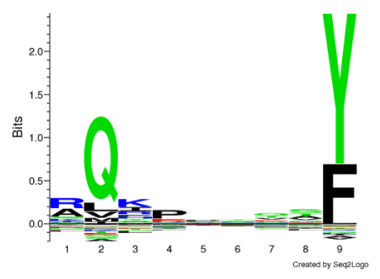

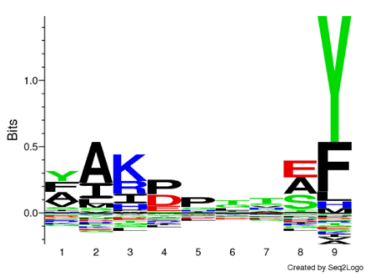

$B * 52: 01$

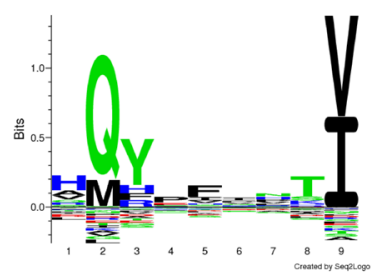

\section{Representative HLA-C}

$C^{*} 01: 02$

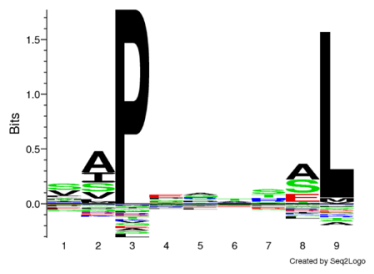

$C * 12: 02$
$\mathrm{C}^{*}$ 04:02

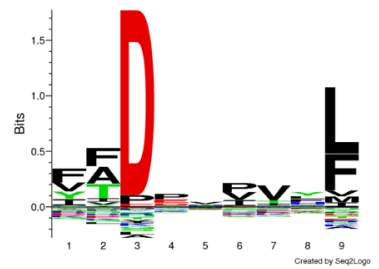

$C * 14: 02$

$C^{*} 07: 02$

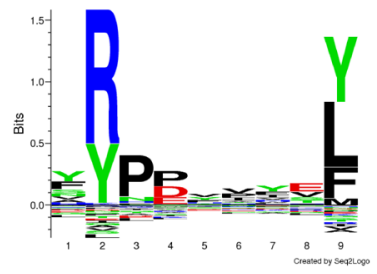

$C^{*} 15: 02$
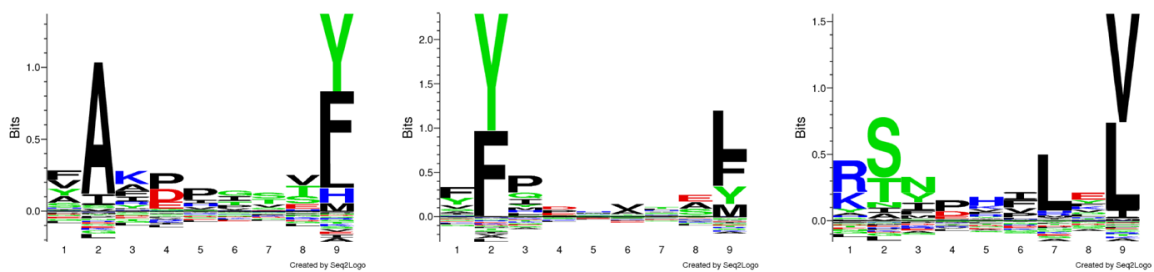

Figure 2. Binding motifs of 9-mer peptides bound to select HLA-A, HLA-B, and HLA-C. Seq2Logo motifs of eluted 9-mer peptides that bind to the specified HLA-A, HLA-B, and HLA-C allotypes grouped by supertype for HLA-A and HLA-B. All motifs are derived on the basis of analysis of eluted peptide sets ${ }^{19}$ (adapted from data freely accessible at: ftp://massive.ucsd.edu/MSV000084172/). Within a given supertype ${ }^{32}$, the peptide motifs are similar. Many HLA-A allotypes lack the strong P2 restriction generally seen in HLA-B and HLA-C. The HLA$B * 07$ allotype binds to peptides that are disfavored by transporter associated with antigen presentation (TAP), and allotypes belonging to this supertype are expressed at low levels on the surface of lymphocytes but at higher levels on TAP-deficient cells ${ }^{33}$. HLA, human leukocyte antigen.

microscopy (cryo-EM) structure of an entire PLC was recently solved at a resolution of $5.8 \AA$ for most components (PDB $6 \mathrm{ENY}$; Figure 1B) 7 . Reconstruction of the low-resolution map was accomplished by superposition of higher-resolution crystal structures. The PLC comprises TAP1, TAP2, and two molecules each of tapasin, peptide-free MHC-I, and calreticulin-ERp57. Of these components, TAP1, TAP2, and tapasin are encoded within the MHC gene complex along with MHC-I heavy chains and function as dedicated assembly factors. Additionally, the PLC comprises two generic co-chaperones of the ER: the glycoprotein-specific chaperone calreticulin and the thiol oxidoreductase ERp579. In the PLC, peptide-deficient MHC-I interacts with tapasin at two sites. The first site involves the interaction of membrane-proximal C-terminal domain of 
tapasin with the MHC-I $\alpha_{3}$ domain and $\beta 2 \mathrm{~m}$ interface, close to the CD8-binding region of MHC-I. The second site involves the interaction of membrane-distal N-terminal domain of tapasin and MHC-I peptide-binding domain at the $\alpha_{2-1}$ region of MHC-I (Figure 1B). The additional incorporation of the calreticulinERp57 complex into PLC stabilizes the tapasin-MHC interaction via two associations within the PLC: one between the N86-linked glycan of MHC-I and the glycan-binding site of calreticulin and other one formed by a disulfide-linked conjugate between C95 of tapasin and C57 of ERp57. The peptide-deficient form of MHC-I is generally unstable and is the form recruited to the PLC. The structure of the PLC illustrates how a peptide-deficient MHC-I becomes stabilized by multi-pronged interactions with dedicated and generic chaperones ${ }^{7}$. Peptide binding causes the release of peptidebound MHC-I from the PLC, allowing forward trafficking into the Golgi apparatus.

MHC-I molecules are critical for effective immunity, and a functional PLC, in turn, is critical for effective MHC-I assembly. Many viruses and cancers are known to disrupt the functions of components of the PLC to evade immune recognition (reviewed in 34-36). In particular, herpesviruses encode many proteins dedicated to the inhibition of TAP expression or function $^{34}$. A recent study shows that tapasin becomes a degradation target in cells infected with molluscum contagiosum virus, thereby negatively affecting MHC-I assembly ${ }^{37}$. Somatic mutations of calreticulin have recently been reported in a subset of myeloproliferative neoplasms (MPNs). Most of these mutations are mapped to exon 9 of the calreticulin gene and alter the protein reading frame such that the $\mathrm{C}$-terminus of mutant calreticulin becomes enriched in basic amino acids, in contrast to the acidic C-terminus of the wild-type protein ${ }^{38,39}$. The two most common mutations are 52-base pair deletion (type 1) and 5-base pair insertion (type 2) mutations ${ }^{39}$. These mutant proteins are known to be secreted since they lack the KDEL retention sequence (reviewed in 40). The significance of calreticulin in MHC-I antigen presentation was demonstrated in earlier studies that showed downregulation of surface MHC-I and impaired antigen presentation in calreticulindeficient cells ${ }^{41,42}$. Mutants of glycan binding residues of calreticulin show reduced incorporation of calreticulin and MHC-I into PLC and reduced MHC-I assembly and cell surface expression $^{42}$. Interestingly, the surface expression of MHC-I is lower in cells expressing MPN mutants of calreticulin compared with those expressing wild-type protein ${ }^{43}$, despite an intact glycan-binding site on the mutants. The weaker interactions of mutant calreticulin proteins within the PLC and reduced MHC-I surface expression compared with wild-type calreticulin are observed even for recombinant MPN calreticulin mutants engineered to contain a C-terminal KDEL sequence. Notably, within the PLC structure, the C-terminal helix of calreticulin points toward the ER-luminal membrane leaflet and lies close to the C-terminal immunoglobulin-like domain of tapasin ${ }^{7}$ (Figure 1B), and previous studies also show that various (non-MPN) calreticulin mutants negatively influence cellular steady-state levels of tapasin ${ }^{42}$. Loss of interaction between the C-terminal helix of calreticulin and tapasin in the context of mutated calreticulin can be postulated to account for the inability of cells expressing MPN calreticulin mutants to restore the MHC-I surface expression to normal levels even when a KDEL sequence is added to mutant calreticulin proteins ${ }^{43}$. These and other recent findings indicate a role for MPN mutant calreticulin-mediated immunosuppression in tumor development and progression ${ }^{43,44}$ in addition to the more direct cell-transforming potential of the calreticulin mutants ${ }^{40}$.

\section{Some HLA-I variants can acquire peptides via TAP- and tapasin-independent pathways, which may confer immune advantages}

Some HLA-I allotypes are known to be able to load peptides and reach the cell surface even in the absence of a functional TAP or tapasin ${ }^{33,45-49}$. Recent studies involving many of the frequent North American HLA-B allotypes revealed a range of abilities to become expressed under TAP- or tapasin-deficient conditions $^{33,49}$. These findings suggest the widespread prevalence of allotypes for which the conventional assembly routes are non-essential for measurable surface expression. Considerable attention in the field has been focused on the mechanisms that govern tapasin- and TAP-independent cell surface expression. Generally, but not in every case, the degrees of TAP-independent and tapasin-independent expression correlate with each other and with the intrinsic stability of a peptide-deficient HLA-B, which allows efficient assembly independently of the assembly factors ${ }^{33,49}$. Additionally, some allotypes have more efficient HLA-I assembly and surface expression under TAP-deficient conditions than others because those HLA-I molecules bind peptides that are better represented within signal sequences or protein transmembrane domains, allowing higher levels of peptide access in the ER lumen independently of $\mathrm{TAP}^{33,45}$. Recent studies involving the analysis of MHC-I peptidomes from spleen cells of TAP-deficient mice found that the peptidome was enriched in signal sequence-derived peptides as well as those derived from precursors in the extracellular space $^{50}$. Notably, endoglycosidase H-resistant forms of HLA-B are detectable on the cell surface under TAP-deficient conditions, indicating a role for unconventional secretory pathways in trafficking of HLA-B from the ER to the cell surface in TAP-deficient cells ${ }^{33}$. Although the nature of these pathways remains to be elucidated, it is possible that this mode of trafficking allows for peptide loading of endocytosed extracellular antigens within endolysosomal compartments. It is also noteworthy that some HLA-B allotypes that display higher levels of expression on TAP-deficient cells bind peptides with a proline residue at the $\mathrm{P} 2$ position, which are disfavored for transport by $\mathrm{TAP}^{51}$, and such HLA-B allotypes are expressed at low levels on the surface of primary lymphocytes ${ }^{52}$. It is possible that such allotypes have evolved to enable some level of antigen presentation under pathogenic conditions in which the normal TAP-dependent pathway becomes blocked.

For some alleles, the peptide repertoire size of MHC-I molecules has been discussed as being correlated to tapasinindependent and TAP-independent expression levels ${ }^{53,54}$. These suggestions are based in part on studies that showed that chicken MHC-I molecules had varying promiscuities of peptide binding (peptide repertoire sizes) that inversely correlated with surface MHC-I expression levels ${ }^{53}$. By 
extension, low-expressing human MHC-I allotypes have been suggested to be promiscuous peptide binders (based on earlier peptide repertoire predictions ${ }^{55,56}$ ) and were noted to be tapasin-independent ${ }^{53}$. More detailed studies showed that, in primary human cells, the cell surface expression patterns of MHC-I molecules were complex and both allele- and cell type-dependent. As noted above, expression variations are determined at least in part by the match between the binding specificities of TAP and the MHC-I allotype ${ }^{52}$. Furthermore, there are at least two major and distinct determinants of a larger peptide repertoire size for a given MHC-I. These are (i) the intrinsic structure of the peptide-binding site that can result in a broader peptide repertoire (examples such as $A * 25: 01$, $\mathrm{B}^{*} 15: 01$, and $\mathrm{C}^{*} 15: 02$ are shown in Figure 2) and (ii) high intrinsic stabilities of the peptide-deficient forms and high efficiencies of peptide loading, which can result in the presentation of suboptimal epitopes under suboptimal assembly conditions relevant to many infections and cancers. Many TAP/tapasin-independent allotypes are expected to be capable of binding and presenting suboptimal epitopes on the basis of their high intrinsic stabilities and efficiencies of peptide loading, but such expanded peptide repertoires may not be captured by conventional LC-MS/MS methods and derived predictive tools, which, as discussed above $^{22}$, are best able to identify high-affinity epitopes. Thus, immunological approaches in addition to predictive and MS approaches are required to define and compare the full peptide repertoire sizes of MHC-I allotypes.

Residue 114 and $116^{47-49,57-59}$ as well as other amino acid positions (residues $97^{60}, 147^{61}$, and $156^{60,62}$ ) are known to be important determinants of tapasin dependence of MHC-I. Molecular dynamics (MD) simulations have been performed of HLA-B allotypes that differ by a single amino acid at position 116 and in their tapasin dependencies ${ }^{61,63-65}$. With some HLA-B pairs, these studies indicate a greater structural stability of the $\mathrm{F}$ pocket (near the peptide C-terminus) of tapasin-independent allotypes in their peptide-deficient forms ${ }^{64-66}$ as well as greater $\alpha_{1}$ helix flexibility of peptidebound forms of tapasin-dependent allotypes ${ }^{63}$. In contrast, MD studies with a set of closely related HLA-B pairs found that the tapasin-independent allotype was more dynamic when peptide was absent compared with the tapasin-dependent allotype ${ }^{61}$. Although further studies are needed to compare the dynamics of different sets of tapasin-dependent or tapasin-independent allotypes under similar experimental conditions, these different results with the distinct allelic pairs raise the possibility that distinct sets of conformational variations can influence the degree of tapasin independence. Nuclear magnetic resonance (NMR) studies have shown chemical shift variations in $\beta 2 \mathrm{~m}$ residues at the heavy chain- $\beta 2 \mathrm{~m}$ interface between a pair of tapasin-dependent or tapasin-independent allotypes that differ only at residue $116^{67}$. Such variations can be indicative of potential differences in the stabilities of specific $\beta 2 \mathrm{~m}$-heavy chain complexes in the absence of peptides, which in turn could render the PLC less critical for peptide loading for some allotypes. Remarkably, not only do tapasin and CD8 share a binding site on MHC-I (Figure 1) but CD8, like tapasin, has higher apparent affinity for the peptide-deficient form of MHC-I. Peptide-deficient forms of MHC-I are induced on the cell surface under some conditions, and once there, these forms can engage $\mathrm{CD} 8$ at the immune synapse and enhance antigen-specific immune responses ${ }^{68}$. Thus, MHC-I conformational sensing is used by both ER assembly factors and cell surface receptors for MHC-I.

The identification of TAP-independent routes of peptide transport to the ER has generated interest in the development of strategies to exploit TAP downregulation in cancer for enhancing anti-tumor immunity. In cancers, the proteolytic products of mutated proteins (termed neoantigens) can be assembled with MHC-I for presentation to $\mathrm{CD}^{+} \mathrm{T}$ cells, resulting in the activation of protective anti-tumor $\mathrm{CD}^{+} \mathrm{T}$-cell responses $^{69}$. Such presentation is indispensable for immune control of cancer and for the success of immunotherapy-based cancer treatments. Additionally, TAP-independent routes of peptide transport in tumors with TAP downregulation may allow presentation of MHC-I epitopes called TEIPPs (T-cell epitopes associated with impaired peptide processing) which are derived from non-mutated self-proteins that are not presented by TAP-proficient cells ${ }^{70}$. Several such HLA-A*02:01restricted neoantigens that are potential candidates for cancer immunotherapy have been identified. $\mathrm{CD} 8^{+} \mathrm{T}$ cells specific to these epitopes are present in healthy donors and are not affected by tolerance mechanisms ${ }^{71}$. $\mathrm{T}$ cells against an epitope derived from the leader sequence of LDL receptor-associated protein 1 (LRPAP1) are shown to recognize TAP-deficient tumor cells of different histological origins, but not healthy cells ${ }^{71}$. Based on these findings, recent studies focused on the evaluation of a therapeutic model that involved the use of targeted knockdown of TAP in tumor cells to enhance the efficacy of conventionally used checkpoint inhibitors and to test the potential of TEIPP-based peptide vaccines in cancer therapy ${ }^{72,73}$. The success of these strategies in the clinic, though promising, is bound to be affected by several factors, including the HLA-I genotype of the patients, identity of specific antigens being tested, and the type of cancer.

\section{TAPBPR recognizes peptide-deficient and peptide- filled HLA-I variants}

TAPBPR is structurally related to $\operatorname{tapasin}^{74-77}$ (Figure 1B), but unlike tapasin, TAPBPR does not incorporate into the PLC ${ }^{78}$. It has been found in both the ER and the Golgi apparatus ${ }^{78}$. Similar to tapasin ${ }^{79}$, TAPBPR preferentially binds the peptide-deficient form of MHC-I, and binding of selected peptides to MHC-I can destabilize its association with TAPBPR ${ }^{80,81}$. However, complexes between peptide-bound MHC-I and TAPBPR have been detected for some MHC-I molecules ${ }^{76,77,82}$. The TAPBPR-MHC-I interaction appears to be higher-affinity than tapasin-MHC-I complexes, as stable complexes of MHC-I with TAPBPR but not tapasin are detected by gel filtration chromatography and by analytical ultracentrifugation for the same MHC-I allotype ${ }^{81}$. Thus, it has been possible to study the structure and dynamics of the TAPBPR and MHC-I complexes using crystallography ${ }^{8,75}$ and $\mathrm{NMR}^{76,77}$.

A number of recent studies showed that TAPBPR could function as a peptide exchange catalyst ${ }^{76,77,80,83}$. Consistent with 
these findings, when TAPBPR is knocked out in cell lines, the number of unique peptides presented by MHC-I increases compared with cells expressing TAPBPR ${ }^{80}$. Recent NMR studies provide considerable insights into the dynamics of peptide-MHC-I complexes in the presence and absence of TAPBPR and suggest mechanisms for functional activities of TAPBPR $^{76,77}$. The murine MHC-I molecule H2-D ${ }^{d}$ has been found to undergo specific localized conformational variations at sites of TAPBPR binding. Both peptides and TAPBPR individually mitigate the measured conformational dynamics of MHC-I. TAPBPR is suggested to function as a chaperone that allows for enhanced kinetic stability of peptide-MHC-I. TAPBPR forms a "latch" onto the MHC-I $\alpha_{2-1}$ region which is in dynamic equilibrium between open and closed conformations. High-affinity peptides that form stable interactions within the peptide-binding site can stabilize the closed latch conformation, thereby causing the dissociation of TAPBPR. This model suggests negative allosteric coupling between peptide-MHC-I and TAPBPR-MHC-I ${ }^{76,77}$. Furthermore, deep mutagenesis studies confirm that key TAPBPR binding sites are located within the $\alpha_{2}$ domain of the MHC-I peptide-binding site but that TAPBPR binding is generally tolerant to substitutions in the $\alpha_{1}$ domain $^{77}$. Thus, local folding in a nascent MHC-I molecule may be sufficient to induce TAPBPR binding as a chaperone and this function is suggested to have broad and multi-allele specificity. On the other hand, alleledependent binding of TAPBPR to peptide-bound MHC-I has been found to be related to the distinct dynamic profiles of MHC-I allotypes. Peptide-MHC-I complexes that display high conformational dynamics at the sites of TAPBPR binding (defined by both the identity of bound peptide and the intrinsic features of individual heavy chain) are selectively recognized by TAPBPR and predicted to be subjected to more extensive TAPBPR-mediated editing ${ }^{77}$. A recent study addressed the role of the TAPBPR helical loop called the scoop loop ${ }^{84}$. The loop is proposed to be positioned to interact within the F pocket of the peptide-binding site. This placement of the scoop loop is suggested to generate competition for the incoming peptide substrates and allow the selective binding of only high-affinity substrates with MHC-I ${ }^{84}$. This model remains somewhat controversial, as there are discrepancies in the placement of the loop between the two crystal structures ${ }^{8,75,85}$.

A recent comprehensive analysis of TAPBPR binding to multiple human HLA-I allotypes revealed preferential binding of TAPBPR to HLA-A allotypes over HLA-B and HLA-C ${ }^{82}$. There is an additional hierarchy among the HLA-A allotypes, and members of the $A^{*} 02$ and $A * 24$ supertypes demonstrate preferential binding to TAPBPR. Interestingly, the addition of soluble TAPBPR to cells facilitates peptide exchange on the surface from selected HLA-I allotypes ${ }^{83}$, which can be used to generate peptide-MHC-I libraries in vitro $^{86}$. TAPBPR binding preferences for a given allotype correlate with the ability of TAPBPR to mediate cell surface peptide exchange on the respective allotype ${ }^{82}$. Residues $\mathrm{H} 114$ and Y116 in the F pocket of MHC-I have been found to be key determinants of TAPBPR binding. Additionally, amino acid residue M12, present on HLA-A*68:02, one of the strongest measured TAPBPR binders, has a strong influence on TAPBPR binding. H114 and Y116 are buried within the F pockets of HLA-I molecules forming contacts with C-termini of bound peptides, and their effects on TAPBPR binding are likely driven via an indirect influence on HLA-I residue dynamics, induced by peptide repertoire variations. Similarly, a conformational (rather than direct) influence is predicted for $\mathrm{M} 12^{82}$.

Notably, HLA-B and HLA-C allotypes lack the H114/Y116 residue pattern. Introduction of H114/D116 amino acid residues in the $\mathrm{F}$ pockets of HLA-B induced TAPBPR binding and cell surface peptide exchange. As noted above, residues 114 and 116 have been previously shown to be important (but not the sole) determinants of HLA-B dependencies on tapasin ${ }^{47-49,57-59}$. For a small subset of HLA-I allotypes, the hierarchies of tapasin and TAPBPR binding are matched ${ }^{82}$, suggesting similarities in chaperone requirements and preferences between TAPBPR and tapasin. Nonetheless, numerous HLA-B allotypes display very strong dependencies on tapasin for their cell surface expression whereas TAPBPR binding is poor for these HLA-B allotypes, highlighting important differences between the modes of tapasin and TAPBPR function. Given the structural relatedness of tapasin and TAPBPR ${ }^{8,74-77}$, the molecular basis for such functional differences and the functional basis of the preferential activity of TAPBPR toward HLA-A remain to be elucidated. The functional differences between the two MHC-I-dedicated chaperones are likely driven by the weaker affinity of the tapasin-MHC-I complex compared with the TAPBPR-MHC-I complex, the incorporation of tapasin into the PLC, and subcellular localization differences. Overall, TAPBPR functions as a powerful peptide editor for several HLA-A molecules. Tapasin also functions as a peptide editor for a distinct group of alleles ${ }^{87-89}$, although its assembly-promoting (chaperone) function within the PLC may be dominant ${ }^{90}$.

\section{Summary}

Human MHC-I molecules are highly polymorphic with specific peptide motif preferences that are now being visualized in expanding numbers, which allow more accurate predictions of peptide repertoire sizes and antigenic epitopes. Spliced peptides, originating from distinct protein precursors, and post-translationally modified peptides are components of the peptide repertoires of MHC-I molecules. HLA-I molecules exhibit varying TAP and tapasin dependencies, and there are distinct influences of TAPBPR on HLA-I allotype assembly and surface expression. Several HLA-I molecules are able to bypass the conventional assembly route, which can confer selective immune advantages and be exploited for immunotherapy. The CD8-binding site of MHC-I is a common CD8 and chaperone interaction region, the conformation of which is sensitive to MHC-I peptide occupancy. The finding that CD8 preferentially engages peptide-deficient MHC molecules indicates the existence of common mechanisms of MHC-I conformational sensing by a cell surface receptor and ER chaperones and shows that MHC-I conformational sensing directly influences immunity.

Authors' contributions

Each author contributed to writing and editing. 
1. Jiang J, Natarajan K, Margulies DH: MHC Molecules, T cell Receptors, Natura Killer Cell Receptors, and Viral Immunoevasins-Key Elements of Adaptive and Innate Immunity. Adv Exp Med Biol. 2019; 1172: 21-62. PubMed Abstract | Publisher Full Text

2. Geng J, Raghavan M: CD8aa homodimers function as a coreceptor for KIR3DL1. Proc Natl Acad Sci U S A. 2019; 116(36): 17951-6. PubMed Abstract | Publisher Full Text | Free Full Text

3. Cole DK, Bulek AM, Dolton G, et al.: Hotspot autoimmune T cell receptor binding underlies pathogen and insulin peptide cross-reactivity. J Clin Invest. 2016; 126(9): 3626

PubMed Abstract | Publisher Full Text | Free Full Text

4. Wang R, Natarajan K, Margulies DH: Structural basis of the CD8 alpha beta/MHC class I interaction: Focused recognition orients CD8 beta to a T cell proximal position. J Immunol. 2009; 183(4): 2554-64. PubMed Abstract | Publisher Full Text | Free Full Text | Faculty Opinions Recommendation

5. Shi Y, Qi J, Iwamoto A, et al.: Plasticity of human CD8aa binding to peptideHLA-A*2402. Mol Immunol. 2011; 48(15-16): 2198-202. Publisher Full Text

6. Saunders PM, Pymm P, Pietra G, et al.: Killer cell immunoglobulin-like receptor 3DL1 polymorphism defines distinct hierarchies of HLA class I recognition. J Exp Med. 2016; 213(5): 791-807. PubMed Abstract | Publisher Full Text | Free Full Text

7. Blees A, Januliene D, Hofmann T, et al.: Structure of the human MHC-I peptide-loading complex. Nature. 2017; 551(7681): 525-8. PubMed Abstract | Publisher Full Text | Faculty Opinions Recommendation

8. Jjiang J, Natarajan K, Boyd LF, et al.: Crystal structure of a TAPBPRMHC I complex reveals the mechanism of peptide editing in antigen presentation. Science. 2017; 358(6366): 1064-8. PubMed Abstract | Publisher Full Text | Free Full Text | Faculty Opinions Recommendation

9. Blum JS, Wearsch PA, Cresswell P: Pathways of antigen processing. Annu Rev Immunol. 2013; 31: 443-73.

PubMed Abstract | Publisher Full Text | Free Full Text

10. Raghavan M, Geng J: HLA-B polymorphisms and intracellular assembly modes. Mol Immunol. 2015; $68(2 \mathrm{Pt}$ A): 89-93.

PubMed Abstract | Publisher Full Text | Free Full Text

11. Robinson J, Barker DJ, Georgiou X, et al.: IPD-IMGT/HLA Database. Nucleic Acids Res. 2020; 48(D1): D948-D955.

PubMed Abstract | Publisher Full Text | Free Full Text

12. Osoegawa K, Mallempati KC, Gangavarapu S, et al:: HLA alleles and haplotypes observed in 263 US families. Hum Immunol. 2019; 80(9): 644-60. PubMed Abstract | Publisher Full Text | Free Full Text

13. Blackwell JM, Jamieson SE, Burgner D: HLA and infectious diseases. Clin Microbiol Rev. 2009; 22(2): 370-85, Table of Contents. PubMed Abstract | Publisher Full Text | Free Full Text

14. D'Souza MP, Adams E, Altman JD, et al.: Casting a wider net: Immunosurveillance by nonclassical MHC molecules. PLoS Pathog. 2019; 15(2): e1007567.

PubMed Abstract | Publisher Full Text | Free Full Text | Faculty Opinions Recommendation

15. Bjorkman PJ, Saper MA, Samraoui B, et al.: The foreign antigen binding site and $\mathrm{T}$ cell recognition regions of class $\mathrm{I}$ histocompatibility antigens. Nature. 1987: 329(6139): 512-8. PubMed Abstract | Publisher Full Text

16. Vizcaíno JA, Kubiniok P, Kovalchik KA, et al:: The Human Immunopeptidome Project: A Roadmap to Predict and Treat Immune Diseases. Mol Cell Proteomics. 2020; 19(1): 31-49.

PubMed Abstract | Publisher Full Text | Free Full Text

17. Abelin JG, Keskin DB, Sarkizova S, et al.: Mass Spectrometry Profiling of HLA-Associated Peptidomes in Mono-allelic Cells Enables More Accurate Epitope Prediction. Immunity. 2017; 46(2): 315-26. PubMed Abstract | Publisher Full Text | Free Full Text

18. Faridi P, Li C, Ramarathinam SH, et al:: A subset of HLA-I peptides are not genomically templated: Evidence for cis- and trans-spliced peptide ligands. Sci Immunol. 2018; 3(28): eaar3947.

PubMed Abstract | Publisher Full Text | Faculty Opinions Recommendation

19. Sarkizova S, Klaeger S, Le PM, et al.: A large peptidome dataset improves HLA class I epitope prediction across most of the human population. Nat Biotechnol. 2020; 38(2): 199-209.

PubMed Abstract | Publisher Full Text | Free Full Text |

Faculty Opinions Recommendation

20. Barnstable CJ, Bodmer WF, Brown G, et al.: Production of monoclonal antibodies to group A erythrocytes, HLA and other human cell surface antigens-new tools for genetic analysis. Cell. 1978; 14(1): 9-20. PubMed Abstract | Publisher Full Text

21. Caron E, Kowalewski DJ, Chiek Koh C, et al.: Analysis of Major
Histocompatibility Complex (MHC) Immunopeptidomes Using Mass Spectrometry. Mol Cell Proteomics. 2015; 14(12): 3105-17. PubMed Abstract | Publisher Full Text | Free Full Text

22. C Partridge T, Nicastri A, Kliszczak AE, et al.: Discrimination Between Human Leukocyte Antigen Class I-Bound and Co-Purified HIV-Derived Peptides in Immunopeptidomics Workflows. Front Immunol. 2018; 9: 912. PubMed Abstract | Publisher Full Text | Free Full Text Faculty Opinions Recommendation

23. Purcell AW, Ramarathinam SH, Ternette N: Mass spectrometry-based identification of MHC-bound peptides for immunopeptidomics. Nat Protoc. 2019; 14(6): 1687-707.

PubMed Abstract | Publisher Full Text

24. Vigneron $\mathrm{N}$, Ferrari V, Stroobant $\mathrm{V}$, et al.: Peptide splicing by the proteasome. J Biol Chem. 2017; 292(51): 21170-9.

PubMed Abstract | Publisher Full Text | Free Full Text

25. Hanada KI, Yewdell JW, Yang JC: Immune recognition of a human renal cancer antigen through post-translational protein splicing. Nature. 2004; 427(6971): $252-6$

PubMed Abstract | Publisher Full Text | Faculty Opinions Recommendation

26. Vigneron N, Stroobant V, Chapiro J, et al:: An antigenic peptide produced by peptide splicing in the proteasome. Science. 2004; 304(5670): 587-90. PubMed Abstract | Publisher Full Text | Faculty Opinions Recommendation

27. Liepe J, Marino F, Sidney J, et al:: A large fraction of HLA class I ligands are proteasome-generated spliced peptides. Science. 2016; 354(6310): 354-8. PubMed Abstract | Publisher Full Text | Faculty Opinions Recommendation

28. Mylonas R, Beer I, Iseli C, et al.: Estimating the Contribution of Proteasomal Spliced Peptides to the HLA-I Ligandome. Mol Cell Proteomics. 2018; 17(12): 2347-57.

PubMed Abstract | Publisher Full Text | Free Full Text |

Faculty Opinions Recommendation

29. Engelhard VH, Altrich-Vanlith M, Ostankovitch M, et al:: Post-translational modifications of naturally processed MHC-binding epitopes. Curr Opin Immunol. 2006; 18(1): 92-7.

PubMed Abstract | Publisher Full Text

30. Malaker SA, Penny SA, Steadman LG, et al.: Identification of Glycopeptides as Posttranslationally Modified Neoantigens in Leukemia. Cancer Immunol Res. 2017; 5(5): 376-84.

PubMed Abstract | Publisher Full Text | Free Full Text

31. Abele R, Tampé R: Moving the Cellular Peptidome by Transporters. Front Cell Dev Biol. 2018; 6: 43.

PubMed Abstract | Publisher Full Text | Free Full Text

32. Sidney J, Peters B, Frahm N, et al.: HLA class I supertypes: A revised and updated classification. BMC Immunol. 2008; 9: 1.

PubMed Abstract | Publisher Full Text | Free Full Text

33. Geng J, Zaitouna AJ, Raghavan M: Selected HLA-B allotypes are resistant to inhibition or deficiency of the transporter associated with antigen processing (TAP). PLoS Pathog. 2018; 14(7): e1007171. PubMed Abstract | Publisher Full Text | Free Full Text

34. Trowitzsch S, Tampé R: Multifunctional Chaperone and Quality Control Complexes in Adaptive Immunity. Annu Rev Biophys. 2020; 49: 135-61. PubMed Abstract | Publisher Full Text

35. Hansen $\mathrm{TH}$, Bouvier M: MHC class I antigen presentation: learning from viral evasion strategies. Nat Rev Immunol. 2009; 9(7): 503-13. PubMed Abstract | Publisher Full Text

36. Leone $\mathrm{P}$, Shin EC, Perosa $\mathrm{F}$, et al.: $\mathrm{MHC}$ class I antigen processing and presenting machinery: organization, function, and defects in tumor cells. J Natl Cancer Inst. 2013; 105(16): 1172-87. PubMed Abstract | Publisher Full Text

37. Harvey IB, Wang X, Fremont DH: Molluscum contagiosum virus MC80 sabotages MHC-I antigen presentation by targeting tapasin for ERassociated degradation. PLoS Pathog. 2019; 15(4): e1007711. PubMed Abstract | Publisher Full Text | Free Full Text | Faculty Opinions Recommendation

38. Nangalia J, Massie CE, Baxter EJ, et al.: Somatic CALR mutations in myeloproliferative neoplasms with nonmutated JAK2. N EnglJ Med. 2013, 369(25): 2391-405

PubMed Abstract | Publisher Full Text | Free Full Text |

Faculty Opinions Recommendation

39. Nlampfl T, Gisslinger H, Harutyunyan AS, et al.: Somatic mutations of calreticulin in myeloproliferative neoplasms. N EnglJ Med. 2013; 369(25): 2379-90.

PubMed Abstract | Publisher Full Text | Faculty Opinions Recommendation

40. How J, Hobbs GS, Mullally A: Mutant calreticulin in myeloproliferative neoplasms. Blood. 2019; 134(25): 2242-8.

PubMed Abstract | Publisher Full Text | Free Full Text

41. C Gao B, Adhikari R, Howarth M, et al.: Assembly and antigen-presenting 
function of MHC class I molecules in cells lacking the ER chaperone calreticulin. Immunity. 2002; 16(1): 99-109.

PubMed Abstract | Publisher Full Text | Faculty Opinions Recommendation

42. Del Cid N, Jeffery E, Rizvi SM, et al.: Modes of calreticulin recruitment to the major histocompatibility complex class I assembly pathway. J Biol Chem. 2010; 285(7): 4520-35

PubMed Abstract | Publisher Full Text | Free Full Text

43. Arshad N, Cresswell P: Tumor-associated calreticulin variants functionally compromise the peptide loading complex and impair its recruitment of MHC-I. J Biol Chem. 2018; 293(25): 9555-69. PubMed Abstract | Publisher Full Text | Free Full Text | Faculty Opinions Recommendation

44. Liu P, Zhao L, Loos F, et al.: Immunosuppression by Mutated Calreticulin Released from Malignant Cells. Mol Cell. 2020; 77(4): 748-760.e9. PubMed Abstract | Publisher Full Text | Faculty Opinions Recommendation

45. Wei ML, Cresswell P: HLA-A2 molecules in an antigen-processing mutant cell contain signal sequence-derived peptides. Nature. 1992; 356(6368): 443-6. PubMed Abstract | Publisher Full Text

46. Peh CA, Laham N, Burrows SR, et al.: Distinct functions of tapasin revealed by polymorphism in MHC class I peptide loading. I Immunol. 2000; 164(1): 292-9.

PubMed Abstract | Publisher Full Text

47. Williams AP, Peh CA, Purcell AW, et al.: Optimization of the MHC class I peptide cargo is dependent on tapasin. Immunity. 2002; 16(4): 509-20. PubMed Abstract | Publisher Full Text

48. Zernich D, Purcell AW, Macdonald WA, et al.: Natural HLA class I polymorphism controls the pathway of antigen presentation and susceptibility to viral evasion. J Exp Med. 2004; 200(1): 13-24.

PubMed Abstract | Publisher Full Text | Free Full Text

49. Rizvi SM, Salam N, Geng J, et al.: Distinct assembly profiles of HLA-B molecules. Immunol. 2014; 192(11): 4967-76. PubMed Abstract | Publisher Full Text | Free Full Text | Faculty Opinions Recommendation

50. L Lorente E, Palomo C, Barnea E, et al:: Natural Spleen Cell Ligandome in Transporter Antigen Processing-Deficient Mice.J Proteome Res. 2019; 18(9): 3512-20.

PubMed Abstract | Publisher Full Text | Faculty Opinions Recommendation

51. Uebel S, Kraas W, Kienle S, et al.: Recognition principle of the TAP transporter disclosed by combinatorial peptide libraries. Proc Natl Acad Sci U S A. 1997; 94(17): 8976-81.

PubMed Abstract | Publisher Full Text | Free Full Text

52. Yarzabek B, Zaitouna AJ, Olson E, et al.: Variations in HLA-B cell surface expression, half-life and extracellular antigen receptivity. Elife. 2018; 7 e34961.

PubMed Abstract | Publisher Full Text | Free Full Text

53. Chappell P, Meziane EK, Harrison M, et al.: Expression levels of MHC class I molecules are inversely correlated with promiscuity of peptide binding. Elife. 2015; 4: e05345.

PubMed Abstract | Publisher Full Text | Free Full Text |

Faculty Opinions Recommendation

54. del Val M, Antón LC, Ramos M, et al.: Endogenous TAP-independent MHC-I antigen presentation: Not just the ER lumen. Curr Opin Immunol. 2020; 64 9-14.

PubMed Abstract | Publisher Full Text

55. Kosmrlj A, Read EL, Qi Y, et al.: Effects of thymic selection of the T-cell repertoire on HLA class I-associated control of HIV infection. Nature. 2010; 465(7296): 350-4.

PubMed Abstract | Publisher Full Text | Free Full Text |

Faculty Opinions Recommendation

56. Paul S, Weiskopf D, Angelo MA, et al.: HLA Class I Alleles Are Associated with Peptide-Binding Repertoires of Different Size, Affinity, and Immunogenicity. J Immunol. 2013; 191(12): 5831-9. PubMed Abstract | Publisher Full Text | Free Full Text

57. Park B, Lee S, Kim E, et al.: A single polymorphic residue within the peptidebinding cleft of MHC class I molecules determines spectrum of tapasin dependence.J Immunol. 2003; 170(2): 961-8. PubMed Abstract | Publisher Full Text

58. Thammavongsa V, Raghuraman G, Filzen TM, et al:: HLA-B44 Polymorphisms at Position 116 of the Heavy Chain Influence TAP Complex Binding via an Effect on Peptide Occupancy. J Immunol. 2006; 177(5): 3150-61. PubMed Abstract | Publisher Full Text

59. Turnquist HR, Thomas HJ, Prilliman KR, et al.: HLA-B polymorphism affects interactions with multiple endoplasmic reticulum proteins. Eur J Immunol. 2000; 30(10): 3021-8.

PubMed Abstract | Publisher Full Text

60. Badrinath S, Kunze-Schumacher H, Blasczyk R, et al:: A Micropolymorphism Altering the Residue Triad 97/114/156 Determines the Relative Levels of Tapasin Independence and Distinct Peptide Profiles for HLA-A $\left(^{*}\right) 24$ Allotypes. I Immunol Res. 2014; 2014: 298145.

PubMed Abstract | Publisher Full Text | Free Full Text
61. Bailey A, Dalchau N, Carter R, et al.: Selector function of MHC I molecules is determined by protein plasticity. Sci Rep. 2015; 5: 14928. PubMed Abstract | Publisher Full Text | Free Full Text

62. Dadrinath S, Saunders P, Huyton T, et al.: Position 156 influences the peptide repertoire and tapasin dependency of human leukocyte antigen B*44 allotypes. Haematologica. 2012; 97(1): 98-106. PubMed Abstract | Publisher Full Text | Free Full Text Faculty Opinions Recommendation

63. Narzi D, Becker CM, Fiorillo MT et al: Dynamical Characterization of Two Differentially Disease Associated MHC Class I Proteins in Complex with Viral and Self-Peptides. J Mol Biol. 2012; 415(2): 429-42. PubMed Abstract | Publisher Full Text

64. Aabualrous ET, Fritzsche $S$, Hein $Z$, et al.: $F$ pocket flexibility influences the tapasin dependence of two differentially disease-associated MHC Class I proteins. Eur J Immunol. 2015; 45(4): 1248-57.

PubMed Abstract | Publisher Full Text | Faculty Opinions Recommendation

65. Serçinoğlu O, Ozbek P: Computational characterization of residue couplings and micropolymorphism-induced changes in the dynamics of two differentially disease-associated human MHC class-I alleles. J Biomol Struct Dyn. 2017; 36(3): 724-40.

PubMed Abstract | Publisher Full Text

66. Sieker F, Springer S, Zacharias M: Comparative molecular dynamics analysis of tapasin-dependent and -independent MHC class I alleles. Protein Sci. 2007; 16(2): 299-308.

PubMed Abstract | Publisher Full Text | Free Full Text

67. Beerbaum M, Ballaschk M, Erdmann N, et al.: NMR spectroscopy reveals unexpected structural variation at the protein-protein interface in MHC class I molecules. J Biomol NMR. 2013; 57(2): 167-78.

PubMed Abstract | Publisher Full Text

68. CGeng J, Altman JD, Krishnakumar S, et al.: Empty conformers of HLA-B preferentially bind CD8 and regulate CD8+ T cell function. Elife. 2018; 7: e36341.

PubMed Abstract | Publisher Full Text | Free Full Text |

Faculty Opinions Recommendation

69. Tran E, Robbins PF, Rosenberg SA: Final common pathway' of human cancer immunotherapy: Targeting random somatic mutations. Nat Immunol. 2017; 18(3): 255-62.

PubMed Abstract | Publisher Full Text | Free Full Text

70. V van Hall T, Wolpert EZ, van Veelen P, et al.: Selective cytotoxic T-lymphocyte targeting of tumor immune escape variants. Nat Med. 2006; 12(4): 417-24. PubMed Abstract | Publisher Full Text | Faculty Opinions Recommendation

71. Marijt KA, Blijleven L, Verdegaal EME, et al.: Identification of non-mutated neoantigens presented by TAP-deficient tumors. J Exp Med. 2018; 215(9): 2325-37.

PubMed Abstract | Publisher Full Text | Free Full Text | Faculty Opinions Recommendation

72. Garrido G, Schrand B, Rabasa A, et al.: Tumor-targeted silencing of the peptide transporter TAP induces potent antitumor immunity. Nat Commun. 2019; 10(1): 3773.

PubMed Abstract | Publisher Full Text | Free Full Text |

Faculty Opinions Recommendation

73. Vigneron N, Ferrari V, van den Eynde BJ, et al.: Cytosolic Processing Governs TAP-Independent Presentation of a Critical Melanoma Antigen. Immunol. 2018; 201(7): 1875-88.

PubMed Abstract | Publisher Full Text | Free Full Text

Faculty Opinions Recommendation

74. Dong G, Wearsch PA, Peaper DR, et al.: Insights into MHC class I peptide loading from the structure of the tapasin-ERp57 thiol oxidoreductase heterodimer. Immunity. 2009; 30(1): 21-32.

PubMed Abstract | Publisher Full Text | Free Full Text |

Faculty Opinions Recommendation

75. Thomas C, Tampé R: Structure of the TAPBPR-MHC I complex defines the mechanism of peptide loading and editing. Science. 2017; 358(6366): 1060-4. PubMed Abstract | Publisher Full Text | Faculty Opinions Recommendation

76. NMcShan AC, Natarajan K, Kumirov VK, et al.: Peptide exchange on MHC-I by TAPBPR is driven by a negative allostery release cycle. Nat Chem Biol. 2018; 14(8): 811-20

PubMed Abstract | Publisher Full Text | Free Full Text |

Faculty Opinions Recommendation

77. N McShan AC, Devlin CA, Overall SA, et al.: Molecular determinants of chaperone interactions on MHC-I for folding and antigen repertoire selection. Proc Natl Acad Sci U S A. 2019; 116(51): 25602-13. PubMed Abstract | Publisher Full Text | Free Full Text | Faculty Opinions Recommendation

78. Boyle LH, Hermann C, Boname JM, et al.: Tapasin-related protein TAPBPR is an additional component of the MHC class I presentation pathway. ProC Natl Acad Sci U S A. 2013; 110(9): 3465-70.

PubMed Abstract | Publisher Full Text | Free Full Text |

Faculty Opinions Recommendation 
79. Rizvi SM, Raghavan M: Direct peptide-regulatable interactions between MHC class I molecules and tapasin. Proc Natl Acad Sci U S A. 2006; 103(48): 18220-5. PubMed Abstract | Publisher Full Text | Free Full Text

80. Hermann C, van Hateren A, Trautwein N, et al:: TAPBPR alters MHC class I peptide presentation by functioning as a peptide exchange catalyst. Elife. 2015; 4: e09617.

PubMed Abstract | Publisher Full Text | Free Full Text

81. Morozov GI, Zhao H, Mage MG, et al.: Interaction of TAPBPR, a tapasin homolog, with MHC-I molecules promotes peptide editing. Proc Natl Acad SCi U S A. 2016; 113(8): E1006-E1015.

PubMed Abstract | Publisher Full Text | Free Full Text |

Faculty Opinions Recommendation

82. CIlca FT, Drexhage LZ, Brewin G, et al.: Distinct Polymorphisms in HLA Class I Molecules Govern Their Susceptibility to Peptide Editing by TAPBPR. Cell Rep. 2019; 29(6): 1621-1632.e3.

PubMed Abstract | Publisher Full Text | Free Full Text |

Faculty Opinions Recommendation

83. Ilca FT, Neerincx A, Wills MR, et al.: Utilizing TAPBPR to promote exogenous peptide loading onto cell surface MHC I molecules. Proc Natl Acad Sci U S A. 2018; 115(40): E9353-E9361.

PubMed Abstract | Publisher Full Text | Free Full Text |

PubMed Abstract | Publisher Full Text
Faculty Opinions Recommendation

84. Sagert L, Hennig F, Thomas C, et al.: A loop structure allows TAPBPR to exert its dual function as MHC I chaperone and peptide editor. Elife. 2020; 9: e55326. PubMed Abstract | Publisher Full Text | Free Full Text
85. Margulies DH, Jiang J, Natarajan K: Structural and dynamic studies of TAPBPR and Tapasin reveal the mechanism of peptide loading of MHC-I molecules. Curr Opin Immunol. 2020; 64: 71-9. PubMed Abstract | Publisher Full Text

86. Overall SA, Toor JS, Hao S, et al:: High throughput pMHC-I tetramer library production using chaperone-mediated peptide exchange. Nat Commun. 2020; 11(1): 1909.

PubMed Abstract | Publisher Full Text | Free Full Text

87. Chen M, Bouvier M: Analysis of interactions in a tapasin/class I complex provides a mechanism for peptide selection. EMBO J. 2007; 26(6): 1681-90. PubMed Abstract | Publisher Full Text | Free Full Text Faculty Opinions Recommendation

88. Howarth M, Williams A, Tolstrup AB, et al.: Tapasin enhances MHC class peptide presentation according to peptide half-life. Proc Natl Acad Sci U S A. 2004; 101(32): 11737-42

PubMed Abstract | Publisher Full Text | Free Full Text |

Faculty Opinions Recommendation

89. Wearsch PA, Cresswell P: Selective loading of high-affinity peptides onto major histocompatibility complex class I molecules by the tapasin-ERp57 heterodimer. Nat Immunol. 2007; 8(8): 873-81.

PubMed Abstract | Publisher Full Text | Faculty Opinions Recommendation

90. Zarling AL, Luckey CJ, Marto JA, et al.: Tapasin is a facilitator, not an editor, of class I MHC peptide binding. I Immunol. 2003; 171(10): 5287-95.

PubMed Abstract | Publisher Full Tex 


\section{Open Peer Review}

\section{Current Peer Review Status:}

\section{Editorial Note on the Review Process}

Faculty Reviews are review articles written by the prestigious Members of Faculty Opinions. The articles are commissioned and peer reviewed before publication to ensure that the final, published version is comprehensive and accessible. The reviewers who approved the final version are listed with their names and affiliations.

\section{The reviewers who approved this article are:}

\section{Version 1}

\section{Christian Münz}

Viral Immunobiology, Institute of Experimental Immunology, University of Zürich, Zürich, Switzerland Competing Interests: No competing interests were disclosed.

\section{Nikolaos G Sgourakis}

Department of Chemistry and Biochemistry, University of California Santa Cruz, Santa Cruz, CA, USA

Andrew C. McShan

Department of Chemistry and Biochemistry, University of California Santa Cruz, Santa Cruz, CA, USA

Competing Interests: No competing interests were disclosed.

\section{David Margulies}

Molecular Biology Section, Laboratory of Immune System Biology, NIAID, National Institutes of Health, Bethesda, MD, USA

Competing Interests: No competing interests were disclosed.

The benefits of publishing with F1000Research:

- Your article is published within days, with no editorial bias

- You can publish traditional articles, null/negative results, case reports, data notes and more

- The peer review process is transparent and collaborative

- Your article is indexed in PubMed after passing peer review

- Dedicated customer support at every stage

For pre-submission enquiries, contact research@f1000.com 